\title{
Influence of temperature and food availability on the ecological energetics of the giant scallop Placopecten magellanicus. I. Growth rates of shell and somatic tissue
}

\author{
B. A. MacDonald* \& R. J. Thompson \\ Marine Sciences Research Laboratory, Memorial University of Newfoundland, St. John's, Newfoundland A1C 5S7, Canada
}

\begin{abstract}
Giant scallops Placopecten magellanicus (Gmelin) were collected at different water depths from locations in Newfoundland and New Brunswick. For various depths at 2 sites (Sunnyside and Colinet), monthly measurements were made for $2 \frac{1 / 2}{\mathrm{yr}}$ of water temperature, chlorophyll, energy content of seston, and size-frequency distribution of particulate matter. Somatic and shell growth rates for scallops from several sites in eastern Canada were compared using polynomial regression techniques and/or Von Bertalanffy equations. Faster shell growth and more pronounced somatic growth were recorded for populations growing under the more favourable conditions of food and temperature associated with shallow water, although localized conditions may obscure any general trend.
\end{abstract}

\section{INTRODUCTION}

The influence of environmental conditions such as food availability and temperature on population energy balance and production is an important feature of several recent studies on marine bivalves (Bayne \& Newell 1983). Growth rate and reproductive output are good indicators of the suitability of the environment, as they represent the integrated response of physiological activities in the organism. The approach often adopted has been to compare animals collected along some presumed or measured gradient of environmental quality, including the intertidal zone (Griffiths 1981a), latitudinally separated areas (Barber \& Blake 1983), various water depths (Kautsky 1982a, b, Rodhouse et al. 1984) and different types of habitat (Bayne \& Worrall 1980) including polluted areas (Widdows et al. 1981).

Measurements of growth, food availability and ingested ration are necessary for an understanding of ecological energetics (Widdows et al. 1979, Bayne \& Worrall 1980, Vahl 1980). Suspension feeding bivalves

\footnotetext{
- Present address: Department of Fisheries and Oceans, Pacific Biological Station, Nanaimo, B.C. V9R 5K6, Canada
}

are ideal for such studies because available ration, food uptake and metabolic losses can be measured and the shell often provides a record of growth history (Seed 1976). The influence of temperature and food on the growth of bivalves has been well documented, especially for mytilids (e.g. Widdows 1978, Bayne \& Worrall 1980, Kautsky 1982a, Sprung 1984) and pectinids (e.g. Kirby-Smith \& Barber 1974, Broom \& Mason 1978, Vahl 1980), but with the exception of recent studies by Bayne \& Worrall (1980), Griffiths (1981b), Kautsky (1982b) and Bayne et al. (1983) their effects on reproductive output are less well known.

Growth comparisons among bivalves have been made in absolute, relative and allometric terms (Seed 1973), growth frequently being expressed by the Von Bertalanffy model, which relates some measure of size (usually length) to the age of the animal, although Rafail (1972) and Roff (1980) have proposed polynomial regression as an alternative method for describing growth. Age and growth rate information for bivalves has routinely been obtained from growth rings in the shell (internal and external) or by analysis of size frequency distributions.

Unlike other commercially important bivalves such as oysters, clams and mussels, very little is known of somatic growth and ecological production in the giant 
scallop Placopecten magellanicus, although several studies have provided shell growth information for this species from the following areas: Bay of Fundy (Stevenson \& Dickie 1954, Caddy et al. 1970), Georges Bank (Merrill et al. 1966), Northumberland Strait (Jamieson et al. 1981a), Nova Scotia (Jamieson et al. 1981b) and Gulf of St. Lawrence (D'Amours \& Pilote 1982).

Placopecten magellanicus is found in very shallow water $(\sim 2 \mathrm{~m})$ near its northern distributional limit (the Strait of Belle Isle), but extends to moderate depths $(\sim 200 \mathrm{~m})$ in the more southerly parts of its range, with variable depth patterns at intermediate latitudes. Food availability and temperature conditions may be expected to deteriorate with water depth, and this may represent a natural gradient of environmental quality for $P$. magellanicus. The major objective of our study was to investigate the partitioning of energy resources between growth and reproduction in relation to temperature and food availability at several depths and locations in different years. In this paper we describe the sites in terms of seasonal changes in temperature and seston, and we consider variation in shell height and somatic weight, using Von Bertalanffy and polynomial analyses and rigorous statistical procedures to compare growth curves. Reproduction, reproductive effort and related quantities will be dealt with in a second paper (MacDonald \& Thompson 1985) and elsewhere.

\section{MATERIALS AND METHODS}

Study sites and general measurements. Scallops were collected from 4 locations in eastern Newfoundland by SCUBA divers and from an area in New Brunswick using a Digby dredge (Fig. 1). The primary sites for study were Sunnyside $\left(47^{\circ} 51^{\prime} \mathrm{N}, 53^{\circ} 55^{\prime} \mathrm{W}\right)$ and Colinet $\left(47^{\circ} 10^{\prime} \mathrm{N}, 53^{\circ} 36^{\prime} \mathrm{W}\right)$ which were sampled at approximately monthly intervals. Secondary sites included Clode Sound in Terra Nova National Park (TNNP) $\left(48^{\circ} 27^{\prime} \mathrm{N}, \quad 53^{\circ} 56^{\prime} \mathrm{W}\right)$, Dildo $\left(47^{\circ} 35^{\prime} \mathrm{N}\right.$, $53^{\circ} 36^{\prime} \mathrm{W}$ ) and an area near St. Andrews (10 m samples from $45^{\circ} 03^{\prime} \mathrm{N}, 67^{\circ} 02^{\prime} \mathrm{W}$; $31 \mathrm{~m}$ samples from $45^{\circ} 05^{\prime} \mathrm{N}$, $67^{\circ} 06^{\prime} \mathrm{W}$ and $76 \mathrm{~m}$ samples from $45^{\circ} 04^{\prime} \mathrm{N}, 60^{\circ} 57^{\prime} \mathrm{W}$ ). Complete size ranges of scallops were sampled from the secondary sites at least twice a year, firstly in August (immediately before spawning) and again in October or November (after spawning). Samples were collected from depths of $10 \mathrm{~m}, 20 \mathrm{~m}$ and $31 \mathrm{~m}$, except at Colinet $(6 \mathrm{~m}, 16 \mathrm{~m})$ and St. Andrews $(10 \mathrm{~m}, 31 \mathrm{~m}$ and $76 \mathrm{~m})$.

Individual weights for the gonad and remaining body tissue (somatic) were recorded after drying at $90^{\circ} \mathrm{C}$ for $48 \mathrm{~h}$. Shell height, i.e. the maximum distance between the dorsal (hinge) and ventral margins (Seed 1980), was recorded to the nearest $0.1 \mathrm{~mm}$ using vernier calipers. Owing to possible seasonal differences in shell and somatic growth rates, only those scallops collected from primary sites between July and

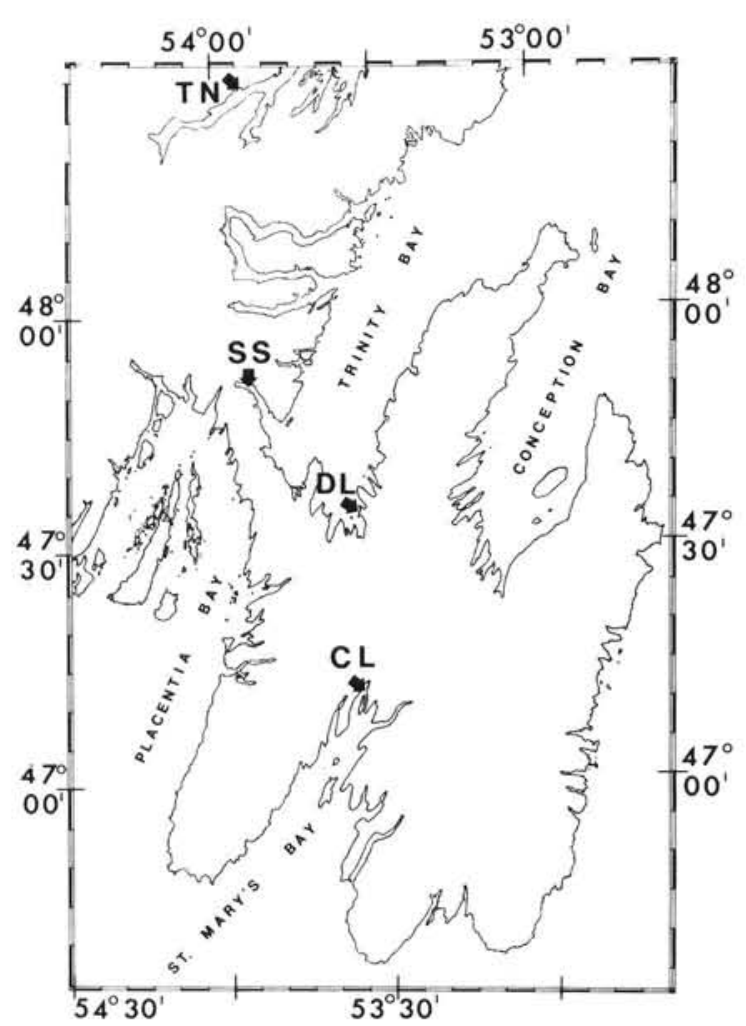

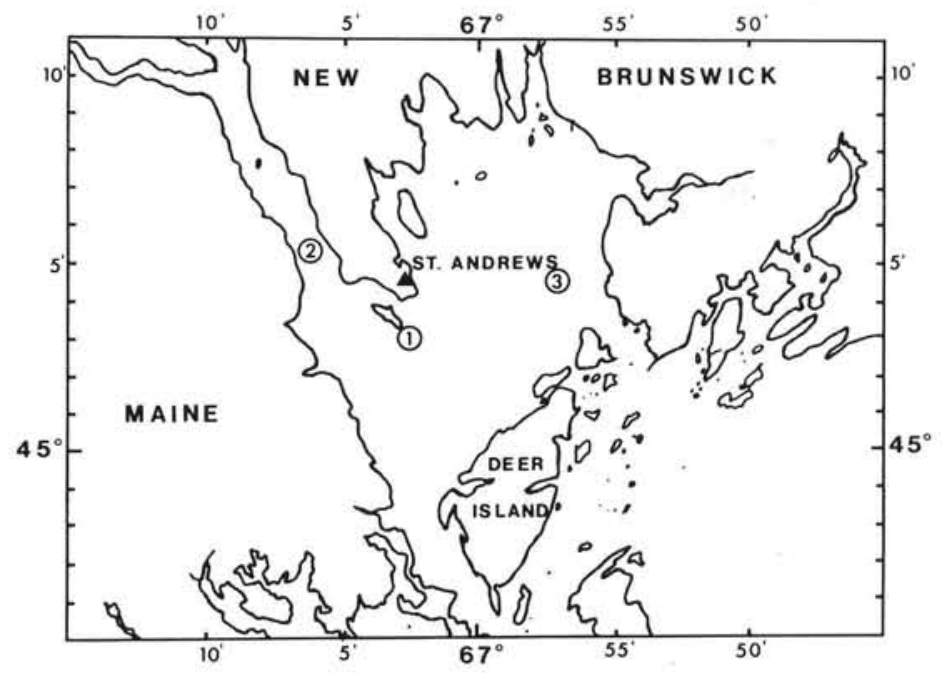

Fig. 1. Locations of collection sites in eastern Newfoundland (SS $=$ Sunnyside, $\mathrm{CL}=$ Colinet, $\mathrm{DL}=$ Dildo, $\mathrm{TN}=$ Terra Nova National Park) and New Brunswick $(1=10 \mathrm{~m}, 2=$ $31 \mathrm{~m}$ and $3=76 \mathrm{~m}$ ) 
December were used in comparisons with secondary sites. Individual ages were estimated by interpreting external growth rings in the shell (Stevenson \& Dickie 1954) and growth increments on the calcareous portion of the ligament (Merrill et al. 1966). We have confidence in this technique, which provided very accurate determinations for scallops of known age reared in cages.

Water temperatures $\left( \pm 0.5 \mathrm{C}^{\circ}\right)$ were recorded by SCUBA divers using a hand-held thermometer or with moored $180 \mathrm{~d}$ continuous recording thermographs (Ryan Instruments, Seattle, Washington).

Seston analysis. Duplicate water samples were obtained from 3 depths at Sunnyside and 2 depths at Colinet approximately once a month. Modified Niskintype water samplers $(\sim 161$ capacity) were manually activated by SCUBA divers approximately 0.6 to $1.2 \mathrm{~m}$ off the bottom. Care was taken to prevent contamination from resuspension of bottom sediments by taking the sample before the divers reached the bottom, or by carrying the sampler in an upstream direction away from any disturbance before activation. Each sampler was immediately emptied into a clean bucket $(\sim 201)$ and the latter sealed for transport back to the laboratory, where each bucket was inverted several times and the water stirred for a few minutes to resuspend any particulate matter that may have settled during the 3 to $6 \mathrm{~h}$ since collection. Each sample was poured through a $300 \mu \mathrm{m}$ screen and then divided into 3 to 41 subsamples for chlorophyll and wet oxidation analysis.

Particulate material was concentrated by filtering the seawater through ashed, pre-weighed Whatman $\mathrm{GF} / \mathrm{F}$ filters ( $5.5 \mathrm{~cm}$ diameter). The filters used for wet oxidation were washed with a few $\mathrm{ml}$ of isotonic ammonium formate before drying at $90^{\circ} \mathrm{C}$ and reweighing. In the case of chlorophyll determinations, approximately $1 \mathrm{ml}$ of a $1 \%$ magnesium carbonate solution was added to the last $100 \mathrm{ml}$ of the sample to inhibit decomposition. Chlorophyll a was immediately extracted in $90 \%$ acetone $\left(15 \mathrm{~h}\right.$ at $4{ }^{\circ} \mathrm{C}$ in darkness) then determined spectrophotometrically as described by Strickland \& Parsons (1972). The energy content of the seston was measured by wet oxidation (Newell 1982).

Approximately every month for 12 mo the particle size distributions in seawater were determined with a Coulter Counter (model $Z_{B}$ ) for 3 depths in Sunnyside, either in the field using portable generator power or immediately upon returning to the laboratory. Each sample was analyzed with a $50 \mu \mathrm{m}$ and a $280 \mu \mathrm{m}$ aperture tube, thereby covering the appropriate size range ( $1 \mu \mathrm{m}$ to $100 \mu \mathrm{m}$ diameter), and the data were then expressed as particle concentration by volume versus log particle-size (Kranck \& Milligan 1979).

Growth comparisons. For the purposes of comparing growth curves from this study and for comparisons with published growth curves, both polynomials and Von Bertalanffy equations were fitted to the shell growth data. Whereas the Von Bertalanffy equation is more familiar and possesses parameters which have biological significance, the polynomial regression affords the advantages that it does not impose asymptotic behaviour (Roff 1980) and is more suitable for comparisons, since it is a linear model. Only polynomials were fitted to the somatic weight data, however, because the curves were clearly non-asymptotic. In order to reduce multicollinearity, values of shell height, $x$, were replaced by $(\mathrm{x}-\overline{\mathrm{x}})$ throughout the study (Neter et al. 1983).

Values for somatic weight and shell height were fitted to the allometric equation $y=a x^{b}$, where $\mathrm{y}=$ somatic weight, $\mathrm{x}=$ shell height, and $\mathrm{a}$ and $\mathrm{b}=$ fitted parameters. When comparing regression parameters (slope and intercept) by means of an analysis of covariance, dummy variables were introduced to the model to consolidate the regressions into a single equation to facilitate analysis and to test the significance of coefficients (Neter et al. 1983). Correlation between the dummy variable and dummy times $\mathrm{x}$ was minimised as described above. The heterogeneity of slopes was first tested, and if the slopes were significantly different at the predetermined significance level (usually $\mathrm{P}<0.05$ ) then the analysis was complete, i.e. the samples came from different populations. However, if the slopes were not significantly different then a common slope was calculated from the samples and a comparison of the elevations was made. If the elevations were different the analysis was complete, whereas if they were similar a common regression equation incorporating all the observations was calculated. This procedure was also followed for comparisons of polynomial growth equations.

When comparisons of more than 2 populations were required it was necessary to use a different approach than simply comparing all possible pairs using 2-sample tests. According to Zar (1984) the use of 2-sample techniques to solve a multisample problem is invalid because the chance of making a Type 1 error (rejecting the null hypothesis when it is true) increases with the number of samples being compared. When multiple comparisons were performed an improvement on the test was made by using the Bonferroni approximation, which simply divides the significance level by $n$, thereby reducing the possibility of a Type 1 error and making the test more conservative (Neter et al. 1983).

Von Bertalanffy curves were fitted by the Marquardt algorithm within the NLIN procedure of the Statistical Analysis System (SAS) package. Comparisons of regression equations were carried out by means of the General Linear Model (GLM) procedure of SAS. 


\section{RESULTS}

\section{Seawater temperature}

At Sunnyside and Colinet, the water temperature was highest in the shallowest depths, with the exception of the winter period (approximately Jan to Apr) when the water column was homogenous (Fig. 2). During the summer a thermocline in less than 20 to $30 \mathrm{~m}$ at Sunnyside resulted in thermal stratification and the greatest temperature differential between water depths, whereas at St. Andrews little difference was observed in temperature throughout the water column to a depth of $53 \mathrm{~m}$, excepting slightly warmer water at the surface and at $24 \mathrm{~m}$ between May and August, and colder surface water in January and February.

Estimates of annual day degrees in each year at every water depth were obtained by multiplying the monthly temperature value by the number of days in the month and summing these values (Table 1). The
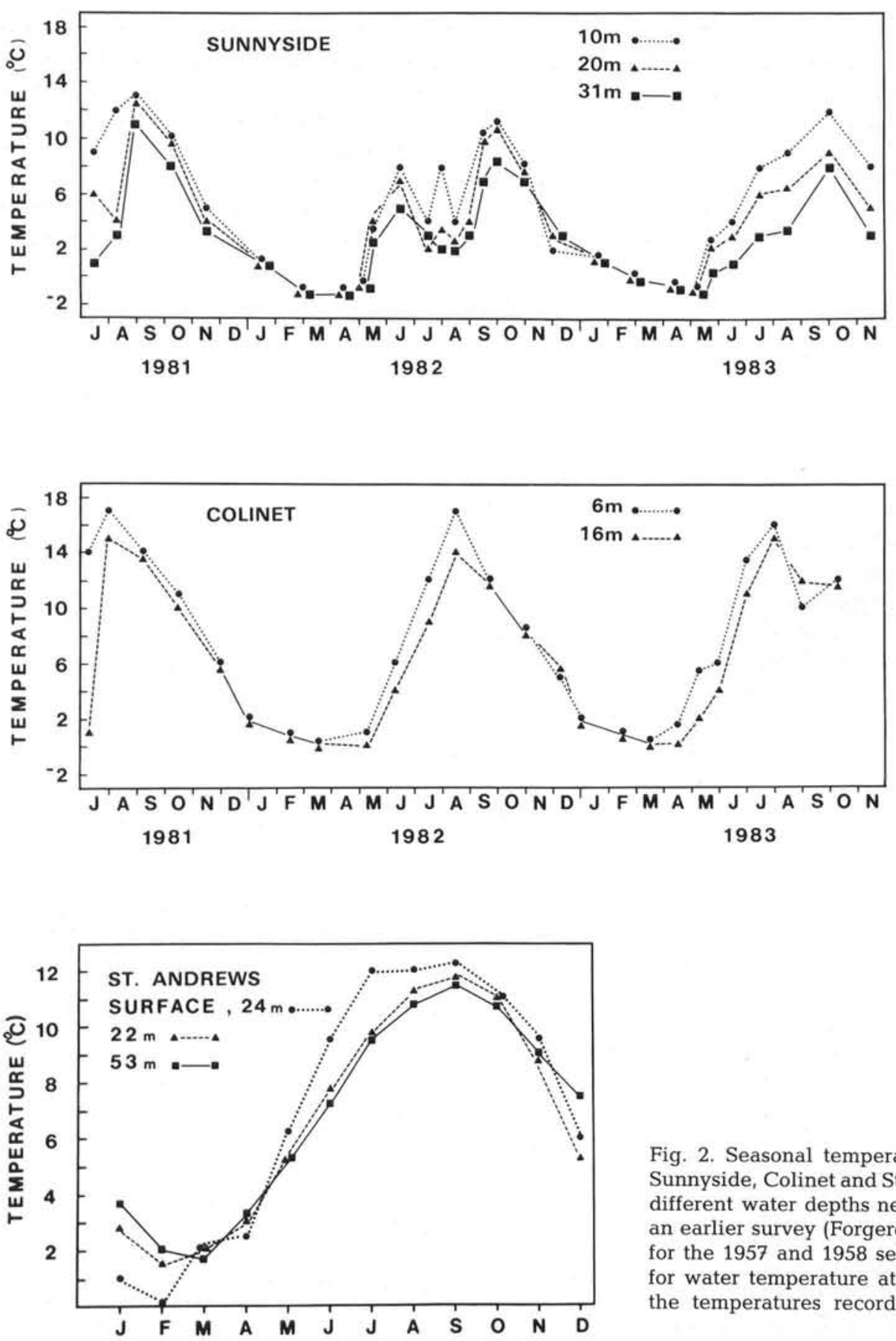

Fig. 2. Seasonal temperature cycles at sampling depths at Sunnyside, Colinet and St. Andrews. Temperature cycles for 3 different water depths near St. Andrews were obtained from an earlier survey (Forgeron 1959) and represent mean values for the 1957 and 1958 seasons combined. An approximation for water temperature at $10 \mathrm{~m}$ was calculated by averaging the temperatures recorded at the surface and the bottom 
Table 1. Estimates of annual day degrees

\begin{tabular}{|cccccccc|}
\hline \multirow{2}{*}{$\begin{array}{c}\text { Depth } \\
(\mathrm{m})\end{array}$} & \multicolumn{3}{c}{ Sunnyside } & \multicolumn{3}{c|}{ Colinet } & \multicolumn{2}{c|}{ TNNP } & \multicolumn{2}{c|}{ St. Andrews } \\
\hline & 1982 & 1983 & 1982 & 1983 & 1983 & 1957 & 1958 \\
\hline 6 & - & - & 2334 & 2338 & - & - & - \\
10 & 1404 & 1497 & - & - & 1530 & 2521 & 2551 \\
16 & - & - & 2004 & 2112 & - & - & - \\
20 & 1239 & 1314 & - & - & 1461 & 2340 & 2460 \\
31 & 1014 & 900 & - & - & 828 & - & - \\
53 & - & - & - & - & - & 2385 & 2550 \\
\hline
\end{tabular}

1982 season was comprised of the months September 1981 (post-spawning) to August 1982 (pre-spawning) inclusive and the 1983 season consisted of the months September 1982 to August 1983.

Whereas the numbers of annual day degrees at TNNP and Sunnyside were similar, there were fewer than for either depth at Colinet. The number of annual day degrees was similar in the 2 yr despite great fluctuations in individual monthly temperatures, e.g. in $10 \mathrm{~m}$ depth at Sunnyside during July and August. Temperatures were slightly lower in 1958 than in 1957 at St. Andrews, but differences between depths for any particular year were less than $10 \%$ and were occasionally nil, i.e. $10 \mathrm{~m}$ and $53 \mathrm{~m}$ in 1958.

\section{Chlorophyll a concentration}

Chlorophyll a values were greater in summer than in winter at Sunnyside and Colinet (Fig. 3), and there was a marked spring bloom (not observed at Colinet in 1982 , owing to prevention of sampling by ice cover). In general, chlorophyll a concentrations at both sites were greater in shallow water than in deeper water, and were consistently low in $31 \mathrm{~m}$ at Sunnyside, except during the spring bloom. Values were more variable

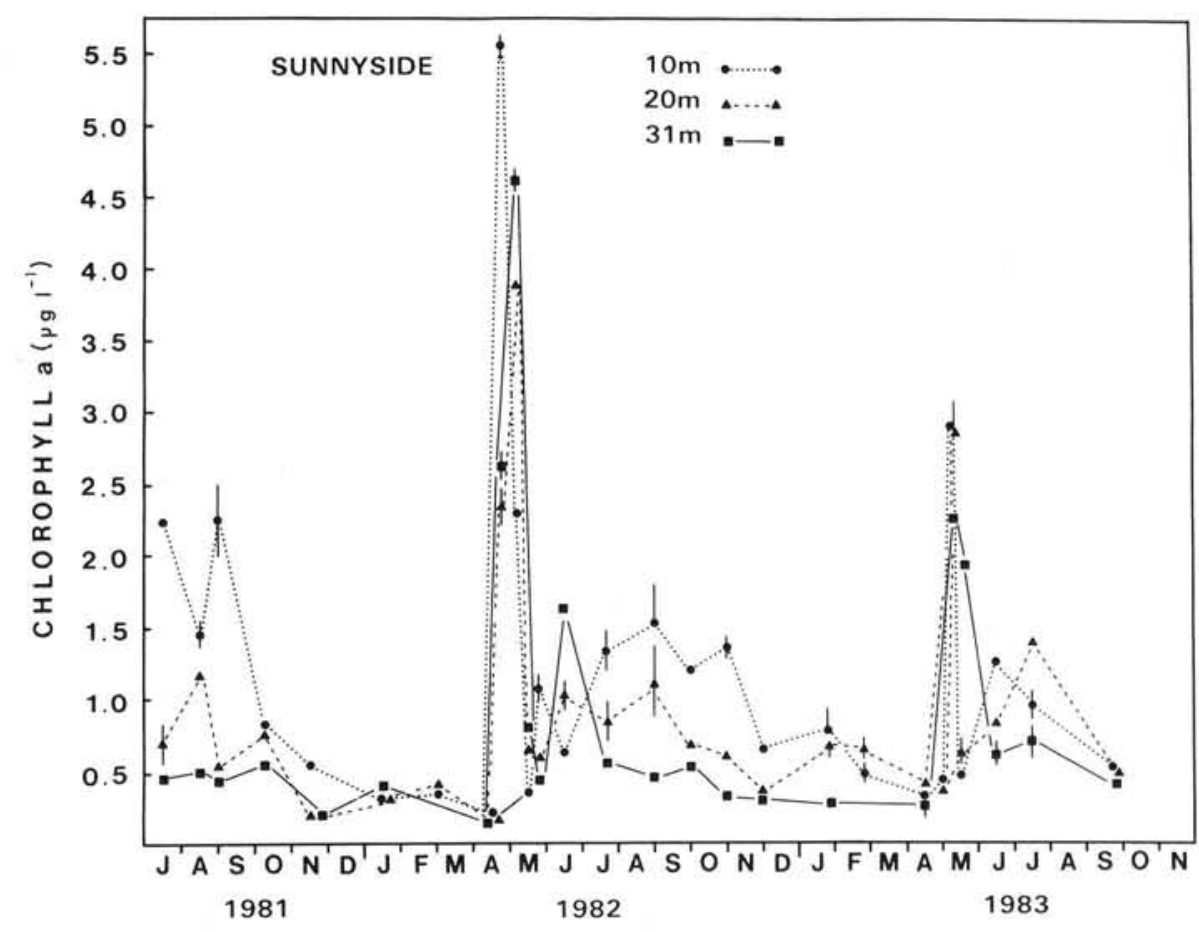

Fig. 3. Seasonal cycles of chlorophyll a concentration at Sunnyside and Colinet. Symbols represent mean values of duplicate analyses and ranges of estimates

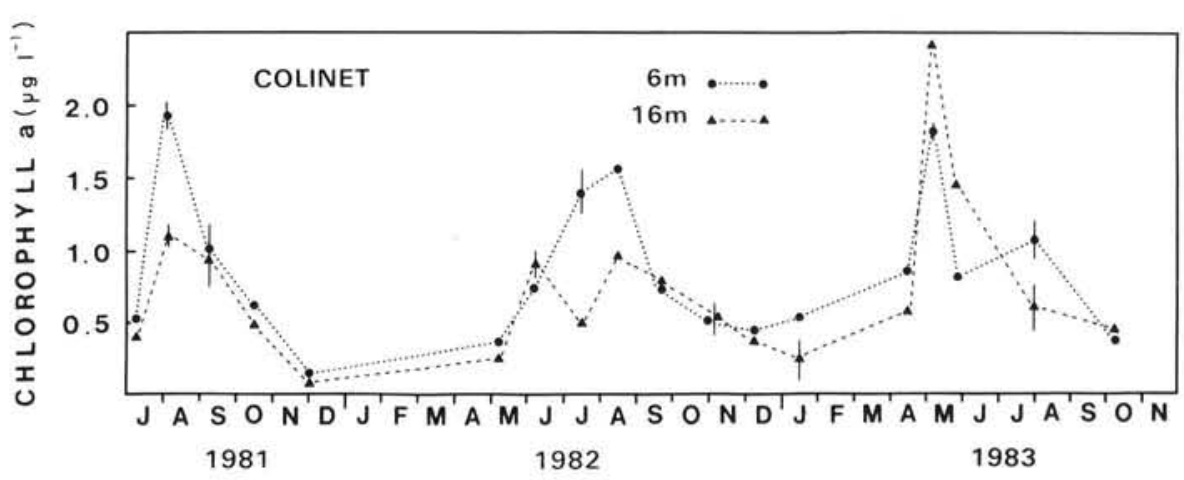


from month to month in $10 \mathrm{~m}$ than in other depths at Sunnyside.

\section{Energy content of seston}

Minimum values (approximately 10 to $15 \mathrm{~J}^{-1}$ ) generally occurred in winter, increasing markedly during the spring bloom in Sunnyside to 65 to $75 \mathrm{~J}^{-1}$ (Fig. 4). Relatively high values of 30 to $50 \mathrm{~J} \mathrm{I}^{-1}$ were also seen in the late summer and autumn. These values were similar to those reported for the Long Island NY area (Newell et al. 1982).

Whereas the energy content of the seston was greatest in the shallowest water from Sunnyside during the earlier half of the study, no consistent depth pattern was seen during the second half of the study, or in the Colinet data. A technique similar to the one used to calculate day degrees was used to integrate the areas under the lines in Fig. 4 in order to obtain an index of
Table 2. Annual food availability $\left(\mathrm{J}^{-1}\right)$

\begin{tabular}{|c|c|c|c|c|}
\hline \multirow[t]{2}{*}{ Depth (m) } & \multicolumn{2}{|c|}{ Sunnyside } & \multicolumn{2}{|c|}{ Colinet } \\
\hline & 1982 & 1983 & 1982 & 1983 \\
\hline 6 & - & - & 6795 & 6765 \\
\hline 10 & 9052 & 6955 & - & - \\
\hline 16 & - & - & 6315 & 6600 \\
\hline 20 & 7917 & 7565 & - & - \\
\hline 31 & 5752 & 7195 & - & - \\
\hline
\end{tabular}

the food available at each depth during the 1982 and 1983 seasons (Table 2). Thus the monthly value of food availability for each depth was multiplied by 30 and summed to give an estimate of annual food availability (cumulative day $\mathrm{J}^{-1}$ ).

A decrease in day $\mathrm{J}^{-1}$ with depth was evident in the 1982 Sunnyside data but the difference was not as distinct at Colinet. In 1983 annual day $\mathrm{J}^{-1}$ were
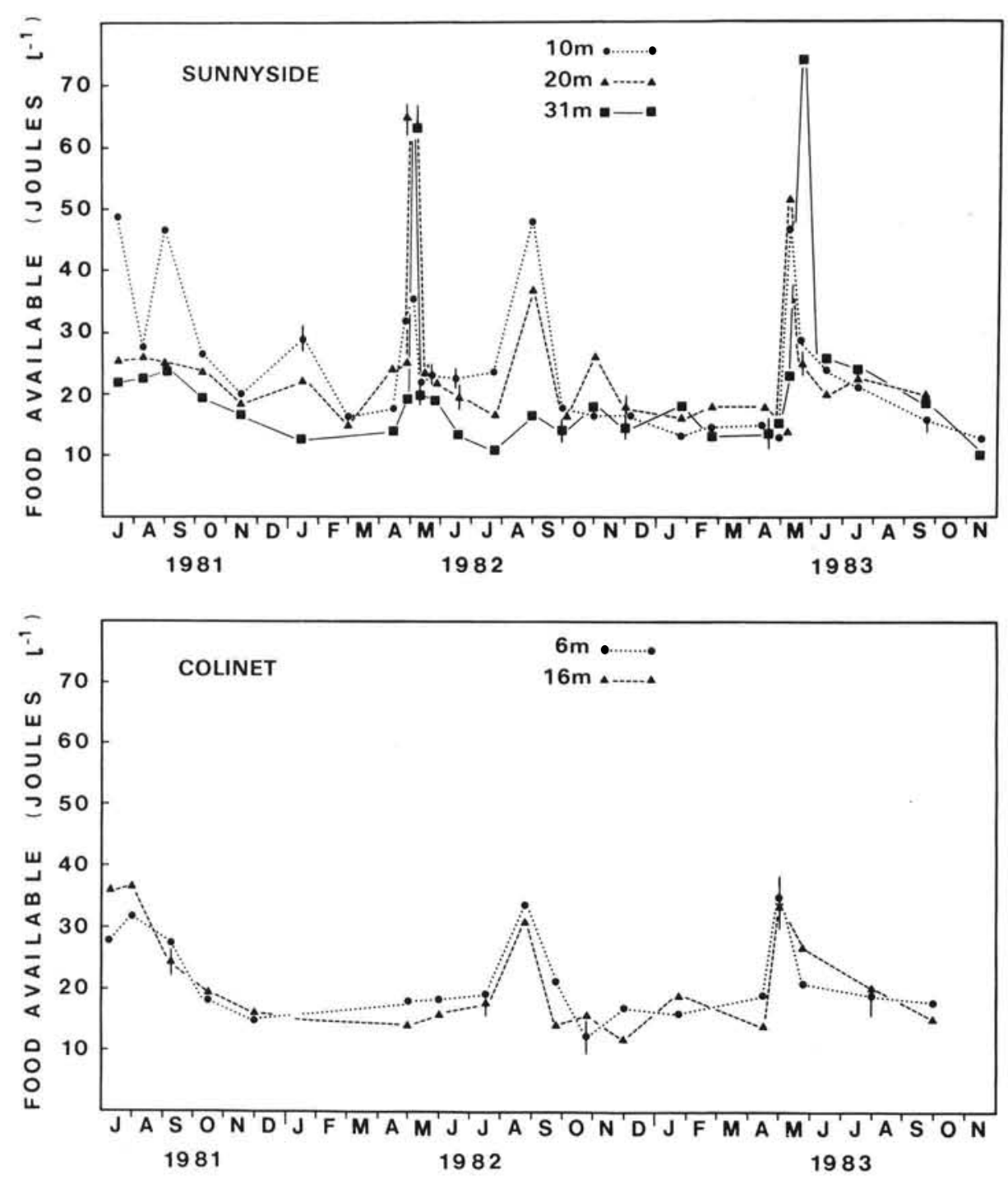

Fig. 4. Seasonal cycle of particulate energy content in Sunnyside and Colinet. Symbols represent mean values of duplicate analyses and ranges of estimates 
greater in $20 \mathrm{~m}$ than in $10 \mathrm{~m}$ at Sunnyside, but differences between depths were slight, and values were lower than in 1982, except at $31 \mathrm{~m}$. In general, values for day $\mathrm{J}^{-1}$ in Colinet were similar to those from $31 \mathrm{~m}$ in Sunnyside but less than those from equivalent depths in Sunnyside.

\section{Particle size distributions}

A classification scheme consisting of 4 basic particle distribution types found in the marine environment (Kranck 1980) was used to describe the distributions from Sunnyside seen in this study. In July 1982, the distribution seen in $10 \mathrm{~m}$ may be described as a Type A or bloom spectrum, which has 1 or more sharp peaks accounting for over half the volume and consisting predominantly of living phytoplankton, plus low background levels consisting of other particles such as miscellaneous plankton cells and detritus (Fig. 5). The distributions seen in the $20 \mathrm{~m}$ and $31 \mathrm{~m}$ samples for the same date may be considered as Type $\mathrm{C}$ or mixed spectra, consisting of a mixture of plankton or detritus having 1 or more plankton peaks superimposed on a poorly sorted background. Alternatively, the $20 \mathrm{~m}$ and $31 \mathrm{~m}$ spectra may be regarded as Type $\mathrm{D}$, or flat spectra, characterized by low total concentrations with similar volumes for all sizes of particles and consisting mainly of living cells plus some detritus.

The particle distributions between October 19, 1982 and May 2, 1983 were of the mixed type with a few plankton peaks, or alternatively the flat type. There was little difference between depths. During this time of year the water column was homogenous, resulting in similar temperature and energy content values, although the chlorophyll values were higher in $10 \mathrm{~m}$ and $20 \mathrm{~m}$ than in $31 \mathrm{~m}$.

The distributions in $10 \mathrm{~m}$ and $20 \mathrm{~m}$ for May 10, 1983 were bloom spectra, whereas a mixed spectrum was evident in $31 \mathrm{~m}$. At this time chlorophyll values had greatly increased, indicating that the spring bloom had begun at water temperatures near zero. Almost a week later, on May 16, the total particle volume in $10 \mathrm{~m}$ and $20 \mathrm{~m}$ had dropped considerably as had the chlorophyll values, but the patterns still met the criteria for bloom spectra. During May a major difference between water depths became apparent as particle volume greatly increased in $31 \mathrm{~m}$, chlorophyll concentration remained high and a very marked bimodal spectrum was seen, indicating that the phytoplankton bloom was still in progress in the deeper water.

During June and July 1983 there were no great differences in spectral types between depths. The spectra may be classified as either the mixed or the bloom type, but again the chlorophyll values were highest in $10 \mathrm{~m}$ and $20 \mathrm{~m}$. The particle size distributions observed in this study were similar to those described by Sheldon et al. (1972) for several areas in the western North Atlantic, in which the surface water often displayed bloom or mixed distributions which varied from place to place, whereas relatively flat uniform distributions were characteristic of deeper waters $(>50 \mathrm{~m})$.

\section{Somatic and shell growth rates}

Von Bertalanffy equations described shell growth very well, but polynomials provided better fits to the somatic weight data (Fig. 6, Table 3). Gompertz growth equations were also fitted to the shell growth data, but unrealistically low estimates of asymptotic heights were obtained, perhaps because of the absence of $1 \mathrm{yr}$ old scallops from the samples. More satisfactory results have also been obtained with Von Bertalanffy rather than Gompertz equations for Macoma balthica (Bachelet 1980), Choromytilus meridionalis (Griffiths 1981a) and Mytilus galloprovincialis (Ceccherelli \& Rossi 1984), although Bayne \& Worrall (1980) reached the opposite conclusion in their study of Mytilus edulis.

In any given age class, somatic weight was more variable than shell height as indicated by the larger confidence intervals and lower $\mathrm{r}^{2}$ values for the former (Fig. 6, Table 3). In comparison with the forced asymptotic fit of the Von Bertalanffy function, the less restrictive polynomial equation was especially advantageous in describing the relation between somatic weight and age. For example, in Fig. 6, 12 of the 13 populations containing scallops greater than $12 \mathrm{yr}$ of age (i.e. excluding St. Andrews) displayed a decline in weight after approximately 16 to $17 \mathrm{yr}$, with Colinet $(6 \mathrm{~m})$ the only exception.

\section{Depth related differences}

At Sunnyside, Dildo and TNNP, asymptotic shell height was negatively correlated with depth whereas at St. Andrews and Colinet there were no differences in asymptotic height, $\mathrm{H}_{\infty}$ between depths (Fig. 6, Table 3 \& 4). The growth coefficient $\mathrm{k}$ was independent of depth at Dildo, St. Andrews and Colinet, and there was no difference in $\mathrm{k}$ between scallops from $10 \mathrm{~m}$ and $20 \mathrm{~m}$ at any location. At Sunnyside and TNNP, however, shell growth was slower at $31 \mathrm{~m}$ than in shallower water. These conclusions were confirmed by comparing polynomial regressions of shell height on age, although the polynomial did demonstrate differences in shell growth rate between scallops in $6 \mathrm{~m}$ and 


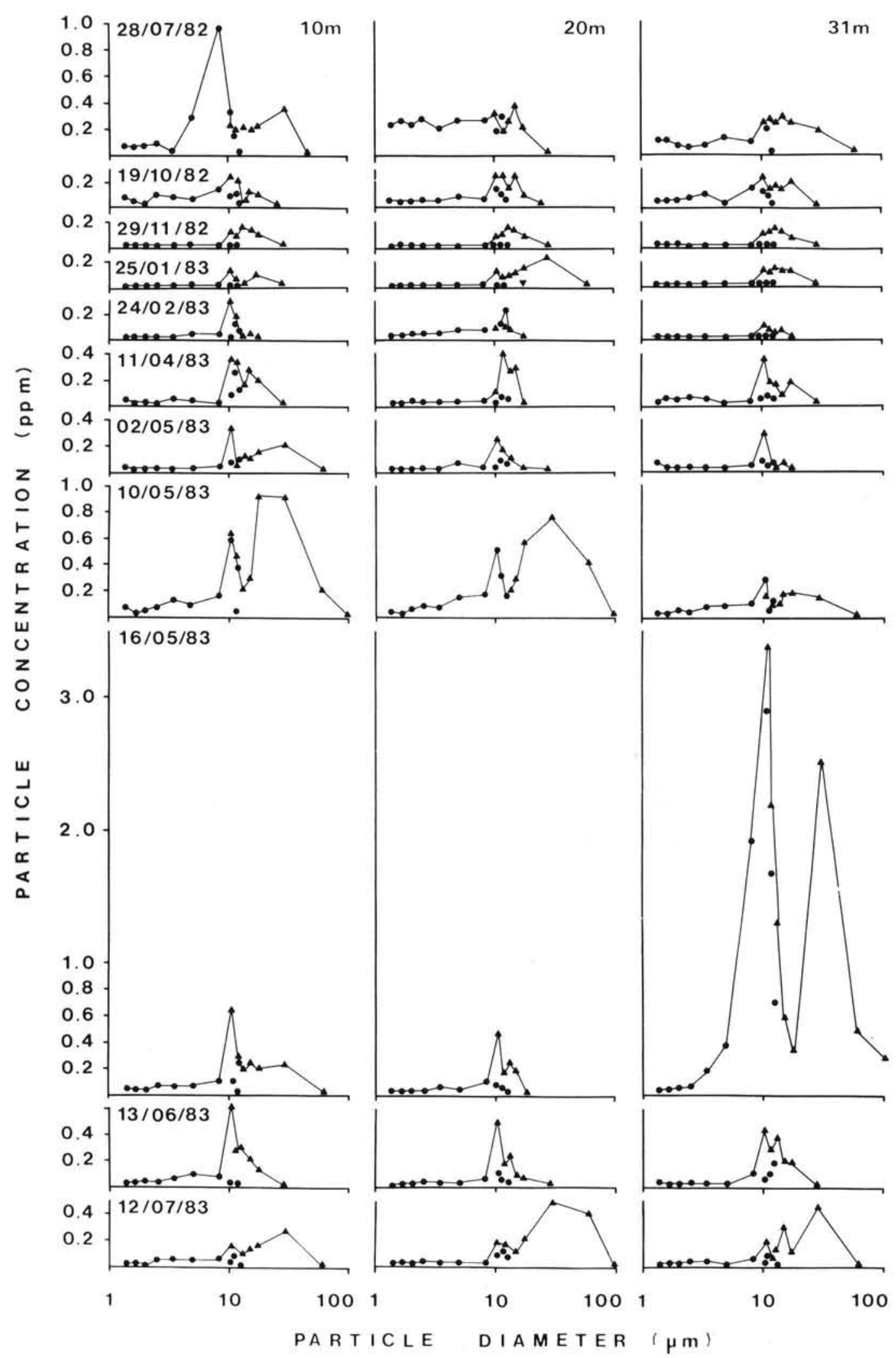

Fig. 5. Particle size spectra for water samples collected in 3 depths at Sunnyside during 1982 and 1983. (४) values obtained with $280 \mu \mathrm{m}$ tube; $(\bullet)$ values obtained with $50 \mu \mathrm{m}$ tube 

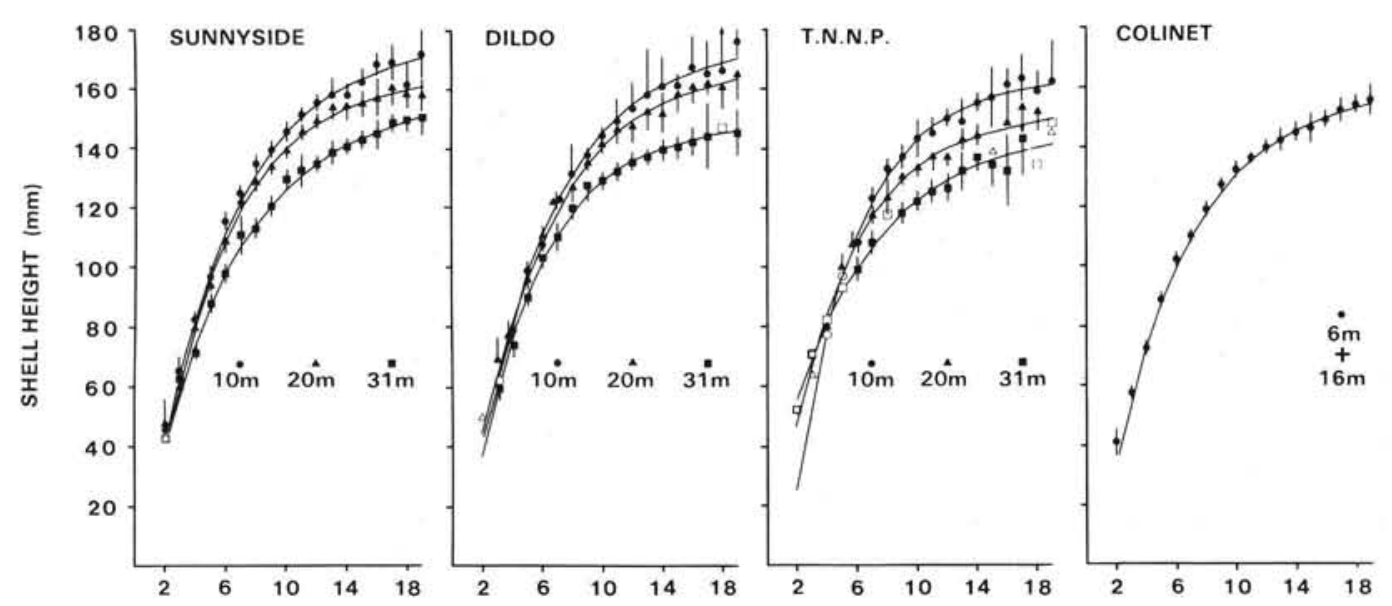

ST. ANDREWS
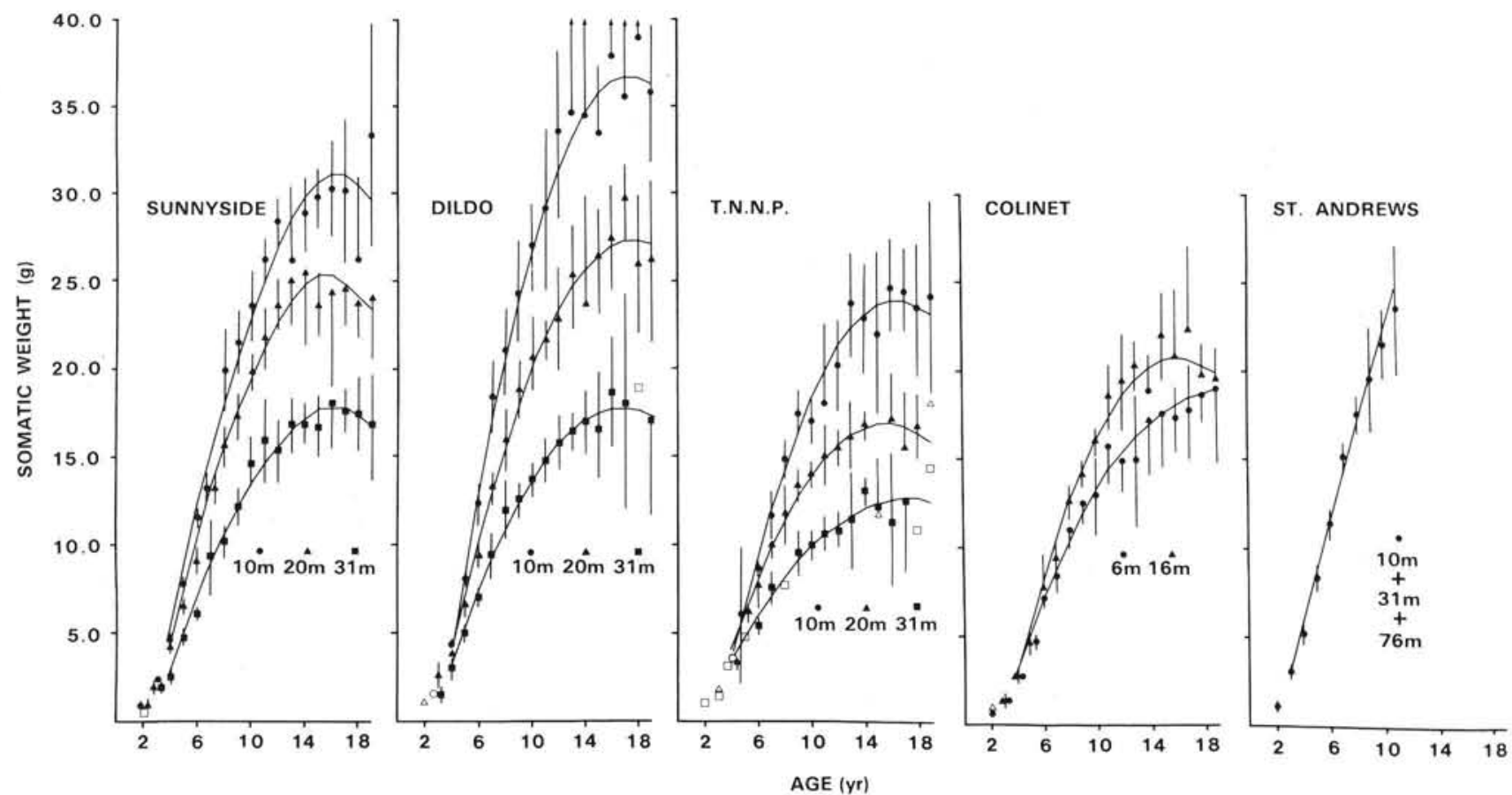

Fig. 6. Placopecten magellanicus. Age-specific shell heights fitted to Von Bertalanffy equations and somatic weights fitted to polynomials for scallop populations from Sunnyside, Dildo, Terra Nova National Park, Colinet and St. Andrews. Mean heights or weights plus $95 \%$ confidence intervals for age classes consisting of $>3$ individuals (solid symbols) and $<3$ individuals (open symbols). $\bar{x}$ values used for polynomial calculations: Sunnyside 9.41; Dildo 10.24; TNNP 10.76; Colinet 9.51; St. Andrews 5.44

$16 \mathrm{~m}$ at Colinet. This was the only example of a discrepancy between comparisons based on the Von Bertalanffy model and those derived from polynomial regression. For brevity, the latter are therefore not presented here.

There was a negative correlation between somatic tissue weight and depth at all locations except Colinet, where the correlation was positive, and St. Andrews, where no differences in somatic growth were observed in scallops from various depths (Fig. 6, Table $3 \& 5$ ). Differences in somatic weight between depths were more pronounced than differences in shell height. For example, at Dildo, where the mean weight of $17 \mathrm{yr}$ old scallops was $17.7 \mathrm{~g}$ in the $31 \mathrm{~m}$ sample and $36.3 \mathrm{~g}$ in the $10 \mathrm{~m}$ sample (a difference of $52 \%$ ), the corresponding heights (167 $\mathrm{mm}$ at $10 \mathrm{~m}, 143.8 \mathrm{~mm}$ at $31 \mathrm{~m})$ differed by only $14 \%$ (Fig. 6).

In order to compare the somatic weights of scallops of given size rather than age, relations between somatic weight and shell height (Table 6) were examined by analysis of covariance (Table 7). In most comparisons, slopes were identical and elevations different, although in a few cases there were significant differences between slopes. In general, somatic weight at 
Table 3. Placopecten magellanicus. Summary of parameters for shell height data (mm) presented in Fig. 6 fitted to the Von Bertalanffy equation $\mathrm{H}_{\mathrm{t}}=\mathrm{H}_{\infty}\left[1-\mathrm{e}^{-\mathrm{k}\left(\mathrm{t}-\mathrm{t}_{0}\right)}\right]$, where $\mathrm{H}_{\mathrm{t}}=$ height at age $\mathrm{t}_{;} \mathrm{H}_{\infty}=$ mean asymptotic height; $\mathrm{k}=$ Brody growth coefficient; $\mathrm{t}_{\mathrm{o}}=\mathrm{a}$ parameter representing time when $\mathrm{H}_{\mathrm{t}}=$ zero. Also parameters for somatic weight data $(\mathrm{g})$ fitted to polynomial regression equations, $y=\beta_{0}+\beta_{1} x+\beta_{2} x^{2}+\beta_{3} x^{3}$ where $x=$ age of scallop (yr); $y=$ predicted somatic weight (g). Regressions represent pooled yearly samples and are all highly significant $(\mathrm{P} \ll 0.001)$

\begin{tabular}{|c|c|c|c|c|c|c|c|c|c|c|c|c|c|c|}
\hline \multicolumn{4}{|c|}{ Sunnyside } & \multicolumn{3}{|c|}{ Dildo } & \multicolumn{3}{|c|}{ TNNP } & \multicolumn{3}{|c|}{ St. Andrews } & \multicolumn{2}{|c|}{ Colinet } \\
\hline & $\begin{array}{c}10 \mathrm{~m} \\
(\mathrm{n}=272)\end{array}$ & $\begin{array}{c}20 \mathrm{~m} \\
(\mathrm{n}=256)\end{array}$ & $\begin{array}{c}31 \mathrm{~m} \\
(\mathrm{n}=243)\end{array}$ & $\begin{array}{c}10 \mathrm{~m} \\
(\mathrm{n}=121)\end{array}$ & $\begin{array}{c}20 \mathrm{~m} \\
(\mathrm{n}=148)\end{array}$ & $\begin{array}{c}31 \mathrm{~m} \\
(\mathrm{n}=137)\end{array}$ & $\begin{array}{c}10 \mathrm{~m} \\
(\mathrm{n}=114)\end{array}$ & $\begin{array}{c}20 \mathrm{~m} \\
(\mathrm{n}=122)\end{array}$ & $\begin{array}{c}31 \mathrm{~m} \\
(\mathrm{n}=94)\end{array}$ & $\begin{array}{c}10 \mathrm{~m} \\
(\mathrm{n}=83)\end{array}$ & $\begin{array}{c}31 \mathrm{~m} \\
(\mathrm{n}=73)\end{array}$ & $\begin{array}{c}76 \mathrm{~m} \\
(\mathrm{n}=58)\end{array}$ & $\begin{array}{c}6 \mathrm{~m} \\
(\mathrm{n}=280)\end{array}$ & $\begin{array}{c}16 \mathrm{~m} \\
(\mathrm{n}=207)\end{array}$ \\
\hline \multicolumn{15}{|c|}{ Shell height vs age (Von Bertalanffy) } \\
\hline $\mathrm{H}_{\infty}$ & 176.5 & 165.5 & 158.4 & 175.4 & 168.2 & 147.8 & 163.1 & 151.1 & 146.0 & 166.9 & 166.0 & 170.2 & 158.6 & 160.1 \\
\hline k & 0.19 & 0.20 & 0.16 & 0.19 & 0.19 & 0.22 & 0.24 & 0.22 & 0.17 & 0.21 & 0.21 & 0.19 & 0.18 & 0.19 \\
\hline$t_{0}$ & 0.55 & 0.63 & 0.10 & 0.66 & 0.37 & 0.74 & 1.26 & 0.37 & -0.88 & 0.51 & 0.53 & 0.20 & 0.54 & 0.72 \\
\hline $\mathrm{r}^{2}$ & 0.97 & 0.97 & 0.97 & 0.97 & 0.96 & 0.97 & 0.90 & 0.94 & 0.92 & 0.96 & 0.98 & 0.97 & 0.96 & 0.96 \\
\hline \multicolumn{7}{|c|}{ Somatic weight vs age (polynomial) } & - & & & & & & & \\
\hline$\beta_{0}$ & 21.19 & 17.96 & 12.25 & 27.20 & 20.25 & 13.84 & 19.29 & 14.48 & 10.25 & 9.91 & 9.45 & 9.97 & 12.39 & 15.13 \\
\hline$\beta_{1}$ & 2.46 & 2.08 & 1.43 & 2.58 & 1.84 & 1.17 & 1.50 & 0.92 & 0.65 & 2.69 & 2.70 & 2.96 & 1.30 & 1.60 \\
\hline$\beta_{2}$ & -0.14 & -0.11 & -0.07 & -0.18 & -0.12 & -0.09 & -0.13 & -0.09 & -0.05 & -0.04 & 0.004 & 0.10 & -0.07 & -0.12 \\
\hline$\beta_{3}$ & -0.005 & -0.006 & -0.003 & - & - & - & - & - & - & - & - & - & - & - \\
\hline $\mathrm{r}^{2}$ & 0.91 & 0.89 & 0.87 & 0.92 & 0.89 & 0.88 & 0.78 & 0.86 & 0.72 & 0.94 & 0.92 & 0.95 & 0.87 & 0.82 \\
\hline
\end{tabular}

Table 4. Placopecten magellanicus. Comparisons of Von Bertalanffy parameters presented in Table 3 for scallops from different depths at each location (* significant; NS: not significant; $\mathrm{P}=0.05$ )

\begin{tabular}{|c|c|c|c|c|c|}
\hline \multirow[t]{2}{*}{ Depth } & \multicolumn{5}{|c|}{ Shell height (Von Bertalanffy) } \\
\hline & $\begin{array}{l}\text { Sunny- } \\
\text { side }\end{array}$ & $\begin{array}{l}\text { Dil- } \\
\text { do }\end{array}$ & TNNP & $\begin{array}{c}\text { St. } \\
\text { Andrews }\end{array}$ & $\begin{array}{l}\text { Coli- } \\
\text { net }\end{array}$ \\
\hline $10 \mathrm{~m} v s 20 \mathrm{~m}$ & & & & $(10 \mathrm{~m} v s 76 \mathrm{~m})$ & $(6 \mathrm{~m} v s 16 \mathrm{~m})$ \\
\hline $\mathrm{H}_{\infty}$ & $\cdot$ & $\cdot$ & $\cdot$ & NS & NS \\
\hline $\mathrm{k}$ & NS & NS & NS & NS & NS \\
\hline$t_{0}$ & NS & NS & $\cdot$ & NS & NS \\
\hline $20 \mathrm{~m} v s 31 \mathrm{~m}$ & & & & $(31 \mathrm{~m} v s 76 \mathrm{~m})$ & \\
\hline $\mathrm{H}_{\infty}$ & $\cdot$ & $\cdot$ & NS & NS & - \\
\hline $\mathrm{k}$ & $\cdot$ & NS & $\cdot$ & NS & - \\
\hline$t_{0}$ & $\cdot$ & NS & $\cdot$ & NS & - \\
\hline $10 \mathrm{~m} v s 31 \mathrm{~m}$ & & & & & \\
\hline $\mathrm{H}_{\infty}$ & • & $\cdot$ & - & NS & - \\
\hline $\mathrm{k}$ & - & NS & • & NS & - \\
\hline$t_{0}$ & $\cdot$ & NS & - & NS & - \\
\hline
\end{tabular}

any given shell height was greater in scallops from shallow water than in those from deeper water, except at Colinet and St. Andrews.

\section{Site related differences}

There were no significant differences between Von Bertalanffy curves describing shell growth in scallops from $10 \mathrm{~m}$ at Sunnyside and Dildo, or between those for scallops from $20 \mathrm{~m}$, but considerable differences were seen between $31 \mathrm{~m}$ samples at these sites (Table 8). Asymptotic height was greater in Dildo scallops at $10 \mathrm{~m}$ and $20 \mathrm{~m}$ than in TNNP scallops at equivalent depths, but there was no difference in $\mathrm{H}_{\infty}$ between samples from $31 \mathrm{~m}$. The parameter $\mathrm{k}$ was greater in TNNP scallops than in Dildo scallops from $10 \mathrm{~m}$, and this was also true for scallops from $20 \mathrm{~m}$, but in $31 \mathrm{~m}$ the reverse was found. At any given depth, scallops from Sunnyside attained a greater asymptotic height than those from TNNP, but there was no difference in $\mathrm{k}$ except at $10 \mathrm{~m}$, where $\mathrm{k}$ was significantly greater for TNNP scallops. In general, scallops from Sunnyside and Dildo were growing at similar rates but faster than those from TNNP or Colinet. Scallops from Colinet were not compared statistically with those from other Newfoundland sites because they were collected from different water depths, but comparisons may be made with the assumption that depths of $6 \mathrm{~m}$ and $16 \mathrm{~m}$ in Colinet are approximately equivalent to $10 \mathrm{~m}$ and $20 \mathrm{~m}$ elsewhere. The maximum heights of scallops from Colinet were less than values reported for comparable depths at other sites, with the exception of $20 \mathrm{~m}$ at TNNP. Scallops from Colinet, Sunnyside and Dildo had similar growth coefficients, but greater $\mathrm{k}$ values were observed in scallops from TNNP.

Comparisons of polynomial equations for somatic weight versus age data were complicated by the fact that the Sunnyside populations had significant cubic coefficients whereas only quadratic terms were significant in the other samples compared (Table 3). This may indicate that Sunnyside was substantially different from other sites or it may be partially attributable to the greater sample sizes, resulting in an improved polynomial fit. In the interests of simplification, the Sunnyside somatic weight data were therefore fitted to quadratic rather than cubic polynomials, so that direct comparisons could be made with other sites. The quadratics for the Sunnyside weight data are given in Table 9. 
Table 5. Placopecten magellanicus. Summary of $\mathrm{t}$ values for comparisons of polynomial regression parameters presented in Table 3 for scallops from different depths at each location. ${ }^{\bullet} \mathrm{P}<0.05 ;{ }^{\cdots} \mathrm{P}<0.01 ; \cdots \mathrm{P}<0.001$

\begin{tabular}{|c|c|c|c|c|c|}
\hline \multirow[t]{2}{*}{ Depth } & \multicolumn{5}{|c|}{ Somatic weight (polynomial) } \\
\hline & Sunnyside & Dildo & TNNP & St. Andrews & Colinet \\
\hline $10 \mathrm{~m}$ vs $20 \mathrm{~m}$ & & & & $(10 \mathrm{~m}$ vs $76 \mathrm{~m})$ & $(6 \mathrm{~m}$ vs $16 \mathrm{~m})$ \\
\hline$\beta_{0}$ & $8.29^{\cdots}$ & $12.75 \cdots$ & $12.00 \cdots$ & 0.14 & $8.48 \cdots$ \\
\hline$\beta_{1}$ & $3.16^{\cdots}$ & $9.56^{\cdots}$ & $7.92 \cdots$ & 1.96 & $5.06^{\cdots}$ \\
\hline$\beta_{2}$ & 0.68 & $3.32 \cdots$ & 2.34 & 2.41 & $4.63^{\cdots}$ \\
\hline$\beta_{3}$ & 0.34 & - & - & - & - \\
\hline $20 \mathrm{~m}$ vs $31 \mathrm{~m}$ & & & & (31 m vs $76 \mathrm{~m})$ & \\
\hline$\beta_{0}$ & $12.69 \cdots$ & $12.87^{\cdots} \cdots$ & $10.77 \cdots$ & 1.15 & - \\
\hline$\beta_{1}$ & $5.33 \cdots$ & $8.96 \cdots$ & $3.45^{\cdots}$ & 1.89 & - \\
\hline$\beta_{2}$ & 2.32 & 2.07 & $2.64^{\cdots}$ & 1.57 & - \\
\hline$\beta_{3}$ & 0.90 & - & - & - & - \\
\hline $10 \mathrm{~m}$ vs $31 \mathrm{~m}$ & & & & & \\
\hline$\beta_{0}$ & $20.06^{\cdots}$ & $24.64 \cdots$ & $22.36^{\cdots}$ & 1.17 & - \\
\hline$\beta_{1}$ & $8.77^{\cdots}$ & $17.86^{\cdots} \cdots$ & $10.36^{\cdots}$ & 0.03 & - \\
\hline$\beta_{2}$ & $2.96^{\cdots}$ & $5.08^{\cdots} \cdots$ & $4.66^{\cdots} \cdots$ & 1.05 & - \\
\hline$\beta_{3}$ & 0.59 & - & - & - & - \\
\hline
\end{tabular}

Table 6. Placopecten magellanicus. Descriptions of somatic weight and shell height data following the allometric relation log y $=\log \mathrm{a}+\mathrm{b} \log \mathrm{x}$, where $\mathrm{x}=$ shell height $(\mathrm{mm}) ; \mathrm{y}=$ predicted somatic weight $(\mathrm{g})$ for a scallop of given size. All regressions highly significant $(\mathrm{P} \ll 0.001)$

\begin{tabular}{|c|c|c|c|c|c|c|c|c|c|c|c|c|c|c|}
\hline & \multicolumn{3}{|c|}{ Sunnyside } & \multicolumn{3}{|c|}{ Dildo } & \multicolumn{3}{|c|}{ TNNP } & \multicolumn{3}{|c|}{ St. Andrews } & \multicolumn{2}{|c|}{ Colinet } \\
\hline & $10 \mathrm{~m}$ & $20 \mathrm{~m}$ & $31 \mathrm{~m}$ & $10 \mathrm{~m}$ & $20 \mathrm{~m}$ & $31 \mathrm{~m}$ & $10 \mathrm{~m}$ & $20 \mathrm{~m}$ & $31 \mathrm{~m}$ & $10 \mathrm{~m}$ & $31 \mathrm{~m}$ & $76 \mathrm{~m}$ & $6 \mathrm{~m}$ & $16 \mathrm{~m}$ \\
\hline \multicolumn{15}{|l|}{1981} \\
\hline $\log a$ & -4.15 & -4.32 & -4.23 & -4.69 & -4.52 & -4.32 & - & - & - & - & - & - & -4.65 & -4.01 \\
\hline $\mathrm{b}$ & 2.54 & 2.60 & 2.52 & 2.81 & 2.68 & 2.55 & - & - & - & - & - & - & 2.73 & 2.45 \\
\hline $\mathrm{n}$ & 121 & 134 & 122 & 31 & 44 & 48 & - & - & - & - & - & - & 137 & 110 \\
\hline $\mathrm{r}^{2}$ & 0.97 & 0.98 & 0.96 & 0.95 & 0.97 & 0.92 & - & - & - & - & - & - & 0.97 & 0.81 \\
\hline \multicolumn{15}{|l|}{1982} \\
\hline $\log a$ & -4.81 & -4.73 & -4.31 & -4.59 & -4.49 & -4.54 & -4.12 & -4.04 & -4.49 & - & - & - & -4.50 & -4.04 \\
\hline b & 2.83 & 2.79 & 2.55 & 2.76 & 2.69 & 2.68 & 2.49 & 2.43 & 2.63 & - & - & - & 2.64 & 2.44 \\
\hline $\mathrm{n}$ & 82 & 90 & 75 & 51 & 72 & 49 & 71 & 76 & 49 & - & - & - & 85 & 77 \\
\hline $\mathrm{r}^{2}$ & 0.97 & 0.97 & 0.94 & 0.95 & 0.93 & 0.96 & 0.89 & 0.93 & 0.93 & - & - & - & 0.97 & 0.90 \\
\hline \multicolumn{15}{|l|}{1983} \\
\hline $\log a$ & -4.67 & -4.38 & -3.76 & -4.65 & -4.65 & -4.82 & -3.87 & -4.08 & -4.04 & -4.77 & -4.55 & -4.58 & -4.13 & -3.96 \\
\hline $\mathrm{b}$ & 2.77 & 2.62 & 2.28 & 2.80 & 2.76 & 2.83 & 2.36 & 2.42 & 2.40 & 2.83 & 2.72 & 2.75 & 2.47 & 2.39 \\
\hline $\mathrm{n}$ & 93 & 56 & 97 & 56 & 61 & 62 & 34 & 29 & 34 & 83 & 75 & 58 & 68 & 69 \\
\hline $\mathrm{r}^{2}$ & 0.97 & 0.96 & 0.83 & 0.95 & 0.96 & 0.96 & 0.92 & 0.82 & 0.87 & 0.99 & 0.99 & 0.99 & 0.98 & 0.92 \\
\hline
\end{tabular}

For each depth, somatic weight varied between populations (Dildo $>$ Sunnyside $>$ TNNP), except that there was no significant difference between Dildo and Sunnyside scallops from $31 \mathrm{~m}$ (Fig. 6, Table 10). Thus in general, Sunnyside and Dildo scallops not only had greater shell growth rates than scallops from other sites but also greater somatic growth rates.

With one exception (31 m in 1983) regression equations describing somatic weight versus shell length for scallops from TNNP always differed from those for the
Sunnyside and the Dildo samples (Table 11). In the $31 \mathrm{~m}$ comparisons only elevations differed, whereas in the $10 \mathrm{~m}$ and $20 \mathrm{~m}$ samples either the slopes or the elevations were different. These observations are consistent with the large differences in the equations describing shell height, somatic weight and age. Thus not only did the TNNP scallops have smaller increments in shell height and somatic weight per year of growth, but also less body weight for individuals of given height. Differences were seen between Dildo 
Table 7. Placopecten magellanicus. Summary of $\mathrm{t}$ values for comparisons of allometric relations between somatic weight and shell height for scallops collected from different depths at each location. Parameters for these relations are presented in Table 6. $\cdot \mathrm{P}<0.05 ; \cdots \mathrm{P}<0.01 ; \cdots \mathrm{P}<0.001$

\begin{tabular}{|c|c|c|c|c|c|c|c|c|c|c|c|c|}
\hline \multirow[t]{2}{*}{ Depth (m) } & \multicolumn{3}{|c|}{1981} & \multicolumn{4}{|c|}{1982} & \multicolumn{5}{|c|}{1983} \\
\hline & $\begin{array}{l}\text { Sunny- } \\
\text { side }\end{array}$ & Dildo & Colinet & $\begin{array}{l}\text { Sunny- } \\
\text { side }\end{array}$ & Dildo & TNNP & Colinet & $\begin{array}{l}\text { Sunny- } \\
\text { side }\end{array}$ & Dildo & TNNP & $\begin{array}{c}\text { St. } \\
\text { Andrews }\end{array}$ & Colinet \\
\hline $10 \mathrm{~m} v s 20 \mathrm{~m}$ & & & & & & & (6m vs $16 \mathrm{~m})$ & & & & \multicolumn{2}{|c|}{$(10 \mathrm{~m}$ vs $76 \mathrm{~m})(6 \mathrm{~m}$ vs $16 \mathrm{~m})$} \\
\hline a & $5.48 \cdots$ & $5.33 \cdots$ & - & 1.81 & $4.33 \cdots$ & $3.99 \cdots$ & $3.45 \cdots$ & $2.41^{\cdots}$ & 1.14 & $5.16 \cdots$ & $5.27 \cdots$ & 0.69 \\
\hline b & 1.10 & 0.88 & $2.39^{*}$ & 0.58 & 0.61 & 0.45 & 1.90 & 1.03 & 0.41 & 0.27 & 1.43 & 0.90 \\
\hline $20 \mathrm{~m} v s 31 \mathrm{~m}$ & & & & & & & & & & \multicolumn{3}{|c|}{$(31 \mathrm{~m}$ vs $76 \mathrm{~m})$} \\
\hline a & $9.16 \cdots$ & $4.76^{\cdots}$ & - & - & $5.07 \cdots$ & $2.82 *$ & - & $4.58 \cdots$ & $7.14 \cdots$ & 0.86 & $3.24 \cdots$ & - \\
\hline b & 1.46 & 0.96 & - & $2.66^{*}$ & 0.07 & 1.58 & - & 2.28 & 0.65 & 0.08 & 0.28 & - \\
\hline \multicolumn{13}{|c|}{$10 \mathrm{~m} v s 31 \mathrm{~m}$} \\
\hline a & $14.27^{\cdots}$ & $9.29^{\cdots}$ & - & - & $9.33 \cdots$ & $5.99 \cdots$ & - & - & $9.03 \cdots$ & $6.26 \cdots$ & 2.04 & - \\
\hline b & 0.38 & 1.60 & - & $3.08 \%$ & 0.72 & 0.90 & - & $4.53 \cdots$ & 0.24 & 0.16 & 1.78 & - \\
\hline
\end{tabular}

Table 8. Placopecten magellanicus. Comparison of Von Bertalanffy parameters presented in Table 3 for scallops from different locations but equivalent water depths. $\bullet$ Significant; NS: not significant at $\mathrm{P}=0.05$

\begin{tabular}{|c|c|c|c|}
\hline \multirow[t]{2}{*}{ Depth } & \multicolumn{3}{|c|}{ Shell height (Von Bertalanffy) } \\
\hline & $\begin{array}{l}\text { Sunnyside } \\
\text { vs Dildo }\end{array}$ & $\begin{array}{c}\text { Dildo } \\
\text { vs TNNP }\end{array}$ & $\begin{array}{c}\text { Sunnyside } \\
\text { vs TNNP }\end{array}$ \\
\hline \multicolumn{4}{|l|}{$10 \mathrm{~m}$} \\
\hline $\mathrm{H}_{\infty}$ & NS & $\cdot$ & $\cdot$ \\
\hline k & NS & $\cdot$ & $\cdot$ \\
\hline$t_{0}$ & NS & NS & • \\
\hline \multicolumn{4}{|l|}{$20 \mathrm{~m}$} \\
\hline $\mathrm{H}_{\infty}$ & NS & $\cdot$ & $\cdot$ \\
\hline $\mathrm{k}$ & NS & $\cdot$ & NS \\
\hline$t_{0}$ & NS & NS & NS \\
\hline \multicolumn{4}{|l|}{$31 \mathrm{~m}$} \\
\hline $\mathrm{H}_{\infty}$ & $\cdot$ & NS & $\cdot$ \\
\hline k & $\cdot$ & $\cdot$ & NS \\
\hline$t_{0}$ & NS & $\cdot$ & $\cdot$ \\
\hline
\end{tabular}

and Sunnyside scallops at every depth on all occasions. The general trend, with 2 exceptions (10 $\mathrm{m}$ in 1981 and $31 \mathrm{~m}$ in 1983), was for the regressions to have similar slopes and different elevations, so that scallops from these 2 sites had the same shell height at any given age, but Dildo samples had a greater somatic weight.

\section{Annual variation}

Annual variation in age-related somatic weight was examined in the 2 primary sites (Sunnyside and Colinet) at which large samples were collected for 3 consecutive years. The only significant differences were at $16 \mathrm{~m}$ in Colinet, where 1981 was different from 1982 and 1983, and at $31 \mathrm{~m}$ in Sunnyside, where 1982
Table 9. Quadratics for weight data from the Sunnyside site

\begin{tabular}{|cccccc|}
\hline Depth (m) & $\beta_{0}$ & $\beta_{1}$ & $\beta_{2}$ & $\mathrm{n}$ & $\mathrm{r}^{2}$ \\
\hline 10 & 21.36 & 2.27 & -0.14 & 272 & 0.91 \\
20 & 18.18 & 1.84 & -0.13 & 257 & 0.89 \\
31 & 12.55 & 1.31 & -0.09 & 243 & 0.87 \\
\hline
\end{tabular}

Table 10. Placopecten magellanicus. Summary of $\mathrm{t}$ values for the comparisons of polynomial parameters presented in Table 3 for scallops from different locations but equivalent water depths. ${ }^{-P}<0.05 ; \cdots \mathrm{P}<0.01 ; \cdots \mathrm{P}<0.001$

\begin{tabular}{|c|c|c|c|}
\hline \multirow[t]{2}{*}{ Depth } & \multicolumn{3}{|c|}{ Somatic weight (polynomial) } \\
\hline & $\begin{array}{c}\text { Sunnyside } \\
\text { vs Dildo }\end{array}$ & $\begin{array}{l}\text { Dildo } \\
v s \text { TNNP }\end{array}$ & $\begin{array}{c}\text { Sunnyside } \\
\text { vs TNNP }\end{array}$ \\
\hline \multicolumn{4}{|l|}{$10 \mathrm{~m}$} \\
\hline$\beta_{0}$ & $7.00 \cdots$ & $13.56^{\cdots} \cdots$ & $8.84 \cdots$ \\
\hline$\beta_{1}$ & $7.07 \cdots$ & $7.86^{\cdots}$ & $3.61 \cdots$ \\
\hline$\beta_{2}$ & $2.45^{\circ}$ & 2.10 & 0.28 \\
\hline \multicolumn{4}{|l|}{$20 \mathrm{~m}$} \\
\hline$\beta_{0}$ & 1.40 & $13.09^{\cdots} \cdots$ & $13.21 \cdots$ \\
\hline$\beta_{1}$ & $3.47^{\cdots}$ & $10.42 \cdots$ & $8.77 \cdots$ \\
\hline$\beta_{2}$ & 0.64 & 1.78 & $2.54^{\circ}$ \\
\hline \multicolumn{4}{|l|}{$31 \mathrm{~m}$} \\
\hline$\beta_{0}$ & 0.75 & $9.85^{\cdots}$ & $9.73^{\cdots}$ \\
\hline$\beta_{1}$ & 0.17 & $6.38 \cdots$ & $6.94 \cdots$ \\
\hline$\beta_{2}$ & 0.02 & $2.44^{\circ}$ & $2.70^{\cdots}$ \\
\hline
\end{tabular}

differed from 1981 and 1983 (Table 12). Since scallops less than $5 \mathrm{yr}$ old were under-represented in some samples, comparisons were repeated where appropriate, using only those animals older than $4 \mathrm{yr}$. These analyses confirmed the annual variation in somatic growth in $16 \mathrm{~m}$ at Colinet, but demonstrated no significant difference between years in scallops from $31 \mathrm{~m}$ at Sunnyside. 
Table 11. Placopecten magellanicus. Summary of $\mathrm{t}$ values for comparisons of allometric relations between somatic weight and shell height for scallops collected from different locations but equivalent water depths. Parameters for these relations are presented in Table 6. ${ }^{*} \mathrm{P}<0.05 ; \cdots \mathrm{P}<0.01 ; \cdots \mathrm{P}<0.001$

\begin{tabular}{|c|c|c|c|c|c|c|c|c|c|c|c|c|c|c|}
\hline \multirow[t]{3}{*}{ Depth } & \multicolumn{6}{|c|}{ Sunnyside vs Dildo } & \multicolumn{4}{|c|}{ Dildo vs TNNP } & \multicolumn{4}{|c|}{ Sunnyside vs TNNP } \\
\hline & \multicolumn{2}{|c|}{1981} & \multicolumn{2}{|c|}{1982} & \multicolumn{2}{|c|}{1983} & \multicolumn{2}{|c|}{1982} & \multicolumn{2}{|c|}{1983} & \multicolumn{2}{|c|}{1982} & \multicolumn{2}{|c|}{1983} \\
\hline & $\mathrm{a}$ & b & a & $\mathrm{b}$ & a & b & a & b & $\mathrm{a}$ & b & a & b & a & b \\
\hline $10 \mathrm{~m}$ & - & $2.01^{\circ}$ & $5.63^{\cdots}$ & 0.74 & $6.19^{\cdots}$ & 0.28 & $6.52 \cdots$ & 1.94 & - & $2.44^{\circ}$ & - & $2.76^{*}$ & - & $2.45^{\circ}$ \\
\hline $20 \mathrm{~m}$ & $2.86^{\cdots}$ & 1.02 & $2.55^{\circ}$ & 0.95 & $2.05^{\circ}$ & 1.35 & - & $2.11^{*}$ & $8.11 \cdots$ & 1.55 & - & $3.76^{\cdots}$ & $\cdot 6.57 \cdots$ & 0.90 \\
\hline $31 \mathrm{~m}$ & $2.19^{*}$ & 0.29 & $1.98^{*}$ & 1.10 & - & $3.47^{\cdots}$ & $4.28^{\cdots}$ & 0.38 & $4.30 \cdots$ & 1.00 & $2.73^{*}$ & 0.57 & 1.23 & 0.29 \\
\hline
\end{tabular}

Table 12. Placopecten magellanicus. Summary of $\mathrm{t}$ values for between-year comparisons of polynomial regression equations describing somatic weight versus age relations for scallops collected from the primary sites, Sunnyside $(10 \mathrm{~m}, 20 \mathrm{~m}, 31 \mathrm{~m})$ and Colinet $(6 \mathrm{~m}, 16 \mathrm{~m})$. Comparisons were initially made with all age classes included and then after omitting the small scallops (ages 2 to 4 yr). $\bullet \mathrm{P}<0.05 ; \cdots \mathrm{P}<0.01 ; \cdots \mathrm{P}<0.001$

\begin{tabular}{|c|c|c|c|c|c|c|c|c|c|c|c|c|}
\hline & \multicolumn{4}{|c|}{1981 vs 1982} & \multicolumn{4}{|c|}{1982 vs 1983} & \multicolumn{4}{|c|}{1981 vs 1983} \\
\hline & $\beta_{0}$ & $\beta_{1}$ & $\beta_{2}$ & $\beta_{3}$ & $\beta_{0}$ & $\beta_{1}$ & $\beta_{2}$ & $\beta_{3}$ & $\beta_{0}$ & $\beta_{1}$ & $\beta_{2}$ & $\beta_{3}$ \\
\hline \multicolumn{13}{|c|}{ Somatic weight vs age (ages 2 to 19 inclusive, polynomial) } \\
\hline $6 \mathrm{~m}$ & 1.39 & 0.27 & 1.55 & - & 0.56 & 0.43 & 0.29 & - & 1.69 & 0.73 & 1.63 & - \\
\hline $10 \mathrm{~m}$ & 0.98 & 1.92 & 0.70 & 1.83 & 2.30 & 0.52 & 1.23 & 0.31 & 1.56 & 1.29 & 0.62 & 1.50 \\
\hline $16 \mathrm{~m}$ & $2.55^{\circ}$ & $2.73^{\cdots}$ & 1.82 & - & 1.83 & 0.75 & 0.72 & - & $4.30^{\cdots}$ & 2.14 & 2.39 & - \\
\hline $20 \mathrm{~m}$ & 0.66 & 1.31 & 0.53 & 1.69 & 1.99 & 1.39 & 1.20 & 1.97 & 1.36 & 0.57 & 0.81 & 0.94 \\
\hline $31 \mathrm{~m}$ & $2.52^{\circ}$ & 0.28 & 1.88 & 0.10 & $2.68^{*}$ & 0.25 & $2.82^{\cdots}$ & 0.33 & 0.28 & 0.69 & 1.51 & 0.61 \\
\hline \multicolumn{13}{|c|}{ Somatic weight vs age (ages 5 to 19 inclusive, polynomial) } \\
\hline $16 \mathrm{~m}$ & $2.56^{\circ}$ & 2.16 & 1.66 & - & 1.36 & 0.86 & 0.08 & - & $3.74 \cdots$ & 1.60 & 1.63 & - \\
\hline $31 \mathrm{~m}$ & 2.42 & 0.05 & 1.39 & 0.36 & 2.18 & 0.08 & 1.76 & 0.28 & 0.18 & 0.04 & 0.30 & 0.08 \\
\hline
\end{tabular}

The logarithmic relationships between somatic weight and shell height were compared for all sites sampled for 2 or more years (Table 13). This analysis is particularly appropriate for determining whether there is annual variation in somatic weight, because it eliminates problems associated with accurately determining age and reduces those caused by missing age classes or small sample sizes. Considerable year-to- year differences were recorded for some depths and sites, and the only scallops displaying no annual variation in somatic weight versus shell height relations were those samples from $10 \mathrm{~m}$ in Dildo. Regressions for TNNP scallops all possessed similar slopes at any given depth, but significantly different elevations, except at $31 \mathrm{~m}$. The general trend at Colinet was similarity of slopes (except for the 1981 and 1983 compari-

Table 13. Placopecten magellanicus. Summary of $\mathrm{t}$ values for between-year comparisons of allometric relations between somatic weight and shell height for scallops from sites sampled in at least 2 consecutive yr. Parameters for these relations are presented in Table 6. ${ }^{\bullet} \mathrm{P}<0.05 ; \cdots \mathrm{P}<0.01 ; \cdots \cdot \mathrm{P}<0.001$. (Depths of $6 \mathrm{~m}$ and $16 \mathrm{~m}$ at Colinet were considered equivalent to $10 \mathrm{~m}$ and $20 \mathrm{~m}$ in this table)

\begin{tabular}{|c|c|c|c|c|c|c|c|c|c|c|c|}
\hline \multicolumn{2}{|c|}{ Depth } & \multicolumn{3}{|c|}{1981 vs 1982} & \multicolumn{4}{|c|}{1982 vs 1983} & \multicolumn{3}{|c|}{1981 vs 1983} \\
\hline & & $\begin{array}{l}\text { Sunny- } \\
\text { side }\end{array}$ & Dildo & Colinet & $\begin{array}{l}\text { Sunny- } \\
\text { side }\end{array}$ & Dildo & Colinet & TNNP & $\begin{array}{l}\text { Sunny- } \\
\text { side }\end{array}$ & Dildo & Colinet \\
\hline \multirow[t]{2}{*}{$10 \mathrm{~m}$} & $a$ & - & 0.06 & $2.26^{*}$ & 1.40 & 1.28 & $3.25^{*}$ & $2.47^{\circ}$ & - & 1.11 & - \\
\hline & b & $4.43 \cdots$ & 0.31 & 1.34 & 0.82 & 0.31 & 2.30 & 0.74 & $3.68 \cdots$ & 0.07 & $3.79 \cdots$ \\
\hline \multirow[t]{2}{*}{$20 \mathrm{~m}$} & a & - & $3.22 \cdots$ & $3.66^{\cdots}$ & 0.87 & 1.25 & 2.04 & $3.34^{*}$ & $2.91^{*}$ & $2.48^{\circ}$ & $5.62 \cdots$ \\
\hline & $\mathrm{b}$ & $3.16^{\circ}$ & 0.07 & 0.06 & 1.93 & 0.62 & 0.40 & 0.04 & 0.20 & 0.72 & 0.42 \\
\hline \multirow[t]{2}{*}{$31 \mathrm{~m}$} & $\mathrm{a}$ & 0.46 & 0.46 & - & 1.49 & 2.38 & - & 2.18 & - & $6.13 \cdots$ & - \\
\hline & $\mathrm{b}$ & 0.30 & 0.30 & - & 2.38 & 1.35 & - & 0.96 & $2.43^{\circ}$ & 2.18 & - \\
\hline
\end{tabular}


son in the $6 \mathrm{~m}$ samples) and inequality of elevations (with the exception of the 1982 and 1983 comparison between $16 \mathrm{~m}$ samples). 1981 samples were different from 1982 and 1983 samples for $10 \mathrm{~m}$ and $20 \mathrm{~m}$ depths at Sunnyside, and for $20 \mathrm{~m}$ and $31 \mathrm{~m}$ depths at Dildo. Scallops from $31 \mathrm{~m}$ in Sunnyside in 1982 were similar in somatic weight to those collected in 1981 and 1983, but there were differences in slope in the regressions describing Sunnyside data $(31 \mathrm{~m})$ in 1981 and 1983.

\section{DISCUSSION}

The deeper water environments may be considered less favourable for scallop growth because they have fewer cumulative day degrees and less total ration available to the suspension feeding bivalve. Poorer conditions are reflected in slower shell and somatic growth rates for scallops collected from deeper water. Reduced shell growth in giant scallops from deeper waters has been demonstrated in the Bay of Fundy (Brannen 1940, Caddy et al. 1970) and on Georges Bank (Posgay 1979). Other scallop species, such as Hinnites multirugosus grown in suspended culture off the coast of California (Leighton 1979), and Pecten maximus in Manx waters (Mason 1957), showed similar trends of decreasing shell growth with increasing water depth. All these authors attributed growth differences to food and temperature conditions, although only Posgay (1979) and Leighton (1979) provided quantitative evidence of lower food availability in deeper water. However, Richardson et al. (1982) reported that water depth had no influence on shell growth of cultured Chlamys opercularis from the Firth of Clyde, and Gruffydd (1974) came to the same conclusion when studying natural populations of $P$. maximus in the North Sea.

The observed differences between shallow water populations and deep water populations become even clearer when the age-specific somatic weights are considered. These results are consistent with observations on Hinnites multirugosus by Leighton (1979), and on Mytilus edulis by Kautsky (1982b) and Rodhouse et al. (1984), all of whom reported more rapid shell growth and greater tissue weight in individuals from shallow water than in those from deeper water or growing on the bottom. More rapid tissue and shell growth have also been recorded in mussels (Choromytilus meridionalis) collected at lower levels in the intertidal zone than in mussels from more exposed higher areas (Griffiths 1981a, b).

Larger maximum heights were observed in scallops from shallower water but the rates at which the animals reached their respective asymptotic shell heights were often similar. These observations are consistent with those of Griffiths (1981a), who found little variation in the growth rates of mussels (Choromytilus meridionalis) at different heights on the shore (i.e. along an environmental gradient), but greater asymptotic length, $\mathrm{L}_{\infty}$, values in mussels from the lowest zone, which is the most favourable for feeding. Our data also support the theoretical models presented by Sebens $(1979,1982)$, which suggest that maximum size may be increased by raising the food input, and in the natural situation this factor may at least be partially responsible for establishing the maximum size that the organism may achieve in any particular environment. Greater maximum sizes have been recorded in suspension feeding sea anemones growing in the more favourable lower intertidal zone (Sebens 1982).

Temperature information for the Colinet and St. Andrews sites and food availability data from Colinet reveal very little difference in environmental conditions with changing water depth at these locations. Forgeron (1959) reported that the water column in sections of the Bay of Fundy may be vertically homogenous in terms of salinity and temperature for most of the year due to intense tidal mixing, so the particulate energy may be continually resuspended and evenly distributed throughout the entire water column. These apparently minimal differences are reflected in similar shell growth rates for scallops within each of these 2 sites, regardless of depth. The greater somatic growth for the deeper population in Colinet is the only discrepancy in the general depth trend and may be related to local conditions, such as reduced salinity or greater population density. The similarities in shell growth but differences in somatic growth observed in Colinet populations emphasize the inadequacy of considering only shell morphometric characters as growth indicators.

Scallops from comparable depths at Sunnyside and Dildo (sites in Trinity Bay) exhibit similar shell growth, somatic growth and maximum height. Slower growth rates and smaller maximum sizes are found in scallops from TNNP (Bonavista Bay) and Colinet (St. Mary's Bay) compared with those from Sunnyside and Dildo, suggesting that TNNP and Colinet are less favourable environments. Considerable differences in growth and production have also been observed in mussels (Mytilus edulis) from locations within short distances of one another (Bayne \& Worrall 1980, Bayne et al. 1983, Dickie et al. 1984). Temperature conditions at TNNP are similar to those at the Trinity Bay sites, but information on seston is not available for the former and food may not have been as abundant as at Sunnyside and Dildo. There appears to be less particulate energy at Colinet, but the cumulative day degrees are much greater than those recorded in Trinity Bay. Bayne \& Worrall (1980) have described an instance in 
which somatic growth is lower in a population of mussels (Mytilus edulis) experiencing a greater number of cumulative day degrees than a neighbouring population. The authors considered the former population to be under nutritive and temperature stress at certain times of the year. These findings and those of our study are inconsistent with the very simplistic general concept of increased growth with warmer temperatures for a species within its ecological range of temperatures (Newell 1979), and there is accumulating evidence to support reconsideration of this dogma (for review see Bayne \& Newell 1983). The high temperatures at Colinet may be above the optimum for Placopecten magellanicus in Newfoundland. High water temperatures may result in an increased metabolic energy expenditure which, when coupled with reduced food availability, may decrease growth and maximum size (Sebens 1982).

The major objective of this work was to investigate the influence of food availability and temperature on the growth of scallops by utilizing the gradient which depth provides in the natural environment. This objective was met in that there were good correlations between depth and measured values for food level and temperature, and that differences in these variables were reflected in enhanced growth in shallow water. Taking advantage of this natural and to some extent predictable partitioning of the environment has resulted in a study that complements experimental studies (reviewed by Bayne \& Newell 1983) in which ration and temperature have been manipulated in the laboratory.

Acknowledgements. We thank G. Chaisson, R. Guest, J. Woolridge, R. O'Donnell, J. Ennis and A. Barnes for their valuable assistance in the field, and J. Senciall for help in the laboratory. Samples of scallops from St. Andrews, and laboratory facilities there, were kindly provided by Dr. R. Elner and R. Chandler (Department of Fisheries and Oceans). We acknowledge the enthusiasm and support of Parks Canada personnel, particularly Superintendent R. Orr and Warden J. Tucker at Terra Nova National Park. Considerable assistance with statistical procedures was provided by Dr. A. Cornish. We thank Dr. B. L. Bayne for helpful discussions and for reviewing the manuscript. The work was supported by an NSERC (Canada) operating grant to R.J.T. and by scholarships to B.A.M. from the Marine Sciences Research Laboratory and the Faculty of Graduate Studies, Memorial University of Newfoundland. Marine Sciences Research Laboratory Contribution No. 596.

\section{LITERATURE CITED}

Bachelet, G. (1980). Growth and recruitment of the tellinid bivalve Macoma balthica at the southern limit of its geographical location, the Gironde Estuary (S.W. France). Mar. Biol. 59: 105-117

Barber, B. J., Blake, N. J. (1983). Growth and reproduction of the bay scallop, Argopecten irradians (Lamarck) at its southern distributional limit. J. exp. mar. Biol. Ecol. 66: 247-256

Bayne, B. L., Newell, R. C. (1983). Physiological energetics of marine molluscs. In: Saleuddin, A. S. M., Wilbur, K. M. (ed.) The Mollusca. Vol. 4 (1). Academic Press, New York, p. 407-415

Bayne, B. L., Salkeld, P. N., Worrall, C. M. (1983). Reproductive effort and value in different populations of the marine mussel Mytilus edulis L. Oecologia (Berl.) 59: 18-26

Bayne, B. L., Worrall, C. M. (1980). Growth and production of mussels Mytilus edulis from two populations. Mar. Ecol. Prog. Ser. 3: 317-328

Brannen, R. E. (1940). Growth rate and age group distribution of the giant scallop in the Bay of Fundy. Fish. Res. Bd Can., Mans. Rept. p. 1-8

Broom, M. J., Mason, J. (1978). Growth and spawning in the pectinid Chlamys opercularis in relation to temperature and phytoplankton concentration. Mar. Biol. 47: 277-285

Caddy, J. F., Chandler, R. A., Lord, E. I. (1970). Bay of Fundy scallop surveys (1966 and 1967), with observations on the commercial fishery. Fish. Res. Bd Can. Tech. Rep. 168: 1-9

Ceccherelli, V. U., Rossi, R. (1984). Settlement, growth and production of the mussel, Mytilus galloprovincialis. Mar. Ecol. Prog. Ser. 16: 173-184

D'Amours, D., Pilote, S. (1982). Données biologiques sur le pétoncle d'islande (Chlamys islandica) et le pétoncle géant (Placopecten magellanicus) de la Basse-Côte-Nord du Québec (secteur de la tabatière). Direction generale des pêches maritimes, Québec. Cahier d'information no. 99

Dickie, L. M., Boudreau, P. R., Freeman, K. R. (1984). Influences of stock and site on growth and mortality in the blue mussel (Mytilus edulis). Can. J. Fish. Aquat. Sci. 41: $134-140$

Forgeron, F, D. (1959). Temperature and salinity in the Quoddy region. Chapter 1. In: Passamaquoddy Fisheries Investigations. Report to the International Joint Commission Ottawa and Washington. Appendix I Oceanography p. 1-23

Griffiths, R. J. (1981a). Population dynamics and growth of the bivalve Choromytilus meridionalis (Kr.) at different tidal levels. Estuar. coast. Shelf Sci. 12: 101-118

Griffiths, R. J. (1981b). Production and energy flow in relation to age and shore level in the bivalve Choromytilus meridionalis (Kr.). Estuar. coast. Shelf Sci. 13: 477-493

Gruffydd, Ll. D. (1974). The influence of certain environmental factors on the maximum length of the scallop Pecten maximus (L.). J. Cons. int. Explor. Mer. 35: 300-302

Jamieson, G. S., Witherspoon, N. B., Lundy, M. J. (1981a). Assessment of Northumberland Strait scallop stocks 1980. Can. Tech. Rep. Fish. Aquat. Sci. 1017: 1-44

Jamieson, G. S., Kerr, G., Lundy, M. J. (1981b). Assessment of scallop stocks on Browns and German Banks - 1979. Can. Tech. Rep. Fish. Aquat. Sci. 1014: 1-17

Kautsky, N. (1982a). Growth and size structure in a Baltic Mytilus edulis population. Mar. Biol. 68: 117-133

Kautsky, N. (1982b). Quantitative studies on gonad cycle, fecundity, reproductive output and recruitment in a Baltic Mytilus edulis population. Mar. Biol. 68: 143-160

Kirby-Smith, W. W., Barber, R. T. (1974). Suspension-feeding aquaculture systems: effects of phytoplankton concentration and temperature on growth of the bay scallop. Aquaculture 3: 135-145

Kranck, K. (1980). Variability of particulate matter in a small coastal inlet. Can. J. Fish. Aquat. Sci. 37: 1209-1215

Kranck, K., Milligan, T. (1979). The use of the Coulter 
Counter in studies of particle size-distributions in aquatic environments. Bedford Inst. of Oceanography. Dept. of Fisheries and Oceans. Report Series BI-R-79-7 p. 1-48

Leighton, D. L. (1979). A growth profile for the rock scallop Hinnites multirugosus held at several depths off La Jolla, California. Mar. Biol. 51: 229-232

MacDonald, B. A., Thompson, R. J. (1985). Influence of temperature and food availability on the ecological energetics of the giant scallop Placopecten magellanicus. II. Reproductive output and total production. Mar. Ecol. Prog. Ser. 25: $295-303$

Mason, J. (1957). The age and growth of the scallop Pecten maximus in Manx waters. J. mar. biol. Ass. U.K. 36: 473-492

Merrill, A. S., Posgay, J. A., Nichy, F. E. (1966). Annual marks on shell and ligament of sea scallop Placopecten magellanicus. Fish. Bull. U.S. 65: 299-311

Neter, J., Wasserman, W., Kutner, M. H. (1983). Applied linear regression models. Irwin Publishers, Homeland, nlinois, p. 547

Newell, R. C. (1979). Biology of intertidal animals. Marine Ecological Surveys, Faversham

Newell, R. I. E. (1982). An evaluation of the wet oxidation technique for use in determining the energy content of seston samples. Can. J. Fish. Aquat. Sci. 39: 1383-1388

Newell, R. I. E., Hilbish, T. J., Koehn, R. K., Newell, C. J. (1982). Temporal variation in the reproductive cycle of Mytilus edulis (L.) (Bivalvia: Mytilidae) from localities on the east coast of the United States. Biol. Bull. mar. biol. Lab., Woods Hole 162: 299-310

Posgay, J. A. (1979). Depth as a factor affecting the growth rate of the sea scallop. Coun. Meet. int. Coun. Explor. Sea C.M.-ICES/K: 27

Rafail, S. Z. (1972). Fitting a parabola to growth data of fishes and some application to fisheries. Mar. Biol. 15: 255-264

Richardson, C. A., Taylor, A. C., Venn, T. J. (1982). Growth of the queen scallop Chlamys opercularis in suspended cages in the Firth of Clyde. J. mar. biol. Ass. U.K. 62: 157-169

Rodhouse, P. G., Roden, C. M., Hensey, M. P., Burnell, G. M. McMahon, T., Ottway, B., Ryan, T. H. (1984). Food resource, gametogenesis and growth of Mytilus edulis on the shore and in suspended culture: Killary Habour, Ireland. J. mar. biol. Ass. U.K. 64: 513-529

Roff, D. A. (1980). A motion for the retirement of the Von Bertalanffy function. Can. J. Fish. Aquat. Sci. 37: 127-129
Sebens, K. P. (1979). The energetics of asexual reproduction and colony formation in benthic marine invertebrates. Am. Zool. 19: 683-697

Sebens, K. P. (1982). The limits to indeterminate growth: an optimal size model applied to passive suspension feeders. Ecology 63: 209-222

Seed, R. (1973). Absolute and allometric growth in the mussel, Mytilus edulis L. (Mollusca, Bivalvia). Proc. malac. Soc. Lond. 40: 343-357

Seed, R. (1976). Ecology. In: Bayne, B. L. (ed.) Marine mussels - their ecology and physiology. Cambridge University Press, Cambridge, p. 13-65

Seed, R. (1980). Shell growth and form in the Bivalvia. In: Rhoads, D. C., Lutz, R. A. (ed.) Skeletal growth of aquatic organisms. Plenum Press, New York, p. 23-68

Sheldon, R. W., Prakash, A., Sutcliffe, W. H. Jr. (1972). The distribution of particles in the ocean. Limnol. Oceanogr. 17: $327-340$

Sprung, M. (1984). Physiological energetics of mussel larvae (Mytilus edulis). I. Shell growth and biomass. Mar. Ecol. Prog. Ser. 17: 283-293

Stevenson, J. A., Dickie, L. M. (1954). Annual growth rings and rate of growth of the giant scallop, Placopecten magellanicus (Gmelin) in the Digby area of the Bay of Fundy. J. Fish. Res. Bd Can. 11: 660-671

Strickland, J. D. H., Parsons, T. R. (1972). A practical handbook of seawater analysis. Bull. Fish. Res. Bd Can. 167

Vahl, O. (1980). Seasonal variations in seston and the growth rate of the Iceland scallop, Chlamys islandica (O. F. Müller) from Balsfjord, $70^{\circ}$ N. J. exp. mar. Biol. Ecol. 48: 195-204

Widdows, J. (1978). Combined effects of body size, food concentration and season on the physiology of Mytilus edulis. J. mar. biol. Ass. U.K. 58: 109-124

Widdows, J., Fieth, P., Worrall, C. M. (1979). Relationships between seston, available food and feeding activity in the common mussel Mytilus edulis. Mar. Biol. 50: 195-207

Widdows, J., Phelps, D. K., Galloway, W. (1981). Measurement of physiological condition of mussels transplanted along a pollution gradient in Narragansett Bay. Mar. environ. Res. 4: 181-194

Zar, J. H. (1984). Biostatistical analysis. 2nd ed. Prentice Hall, New Jersey, p. 178 